\title{
Measurement of serum magnesium concentration in type 2 diabetic patients on glibenclamide and metformin therapy
}

\author{
Isam Hamo Mahmood*, Zaynab M. Ali Hassan**, Zeina Satam* \\ *Department of Pharmacology, ** Department of Biochemistry, College of Medicine, University of Mosul.
}

(Ann. Coll. Med. Mosul 2011; 37 (1 \& 2): 14-18).

Received: $9^{\text {th }}$ Jun 2010; Accepted: $25^{\text {th }}$ Apr 2011.

\begin{abstract}
Objectives: To measure serum magnesium concentrations in patients with type 2 diabetes on glibenclamide, metformin or a combination of both drugs therapy in Mosul city.

Patients and Methods: One hundred type 2 diabetic patients formed the patients group. Another group of 27 non diabetic healthy individuals involved in the study as a control group. The patients' group was divided into 3 subgroups according to the type of the oral hypoglycemic agent used (metformin, glibenclamide, metformin plus glibenclamide). The study was conducted in Al Wafaa Diabetes Center in Mosul city, and departments of Pharmacology and Biochemistry, College of Medicine during the period from May 2009 to May 2010. Design of the study is case control. Quantitative analysis of magnesium and glucose in serum were done by using commercial kits.

Results: The results showed a significant lower concentration of magnesium of the patients as compared with the controls and a significant higher serum glucose concentrations of the patients as compared with the controls.
\end{abstract}

Conclusion: This study demonstrated that low magnesium status is common in type 2 diabetics who were on therapy with the hypoglycemic agents, metformin, glibenclamide or a combination of both drugs, in Mosul city.

Keywords: Magnesium, type 2 diabetes mellitus, glibenclamide, metformin.

أهداف البحث: لقياس تركيز مادة المغنيسيوم في مصل دم المرضى الذين يعانون من مرض السكري النوع الثاني والذين

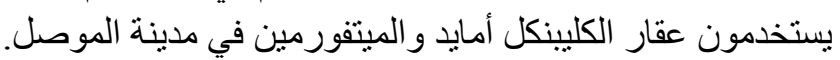

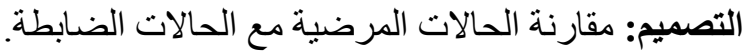

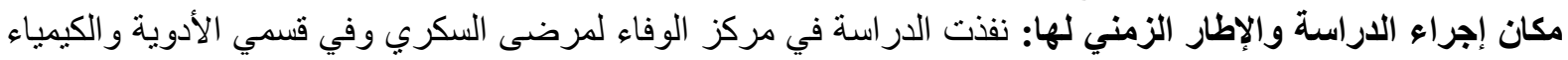

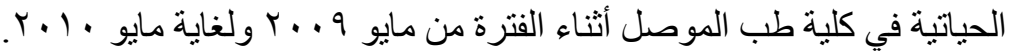
المشاركون: تكونت عينة الحالات المرضية من مائة مريض مصاب بداء السكري النوع الثاني ونتكلت عينة الحالات

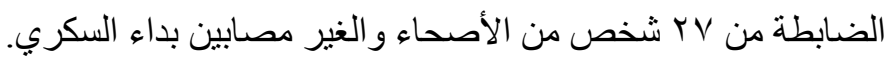
القياسات المستخرجة: تم قياس تركيز المغنيسيوم في مصل دم مرضى السكري ومقارنة النتائج إحصائيا مع القياسات التي تعود للحالات الضابطة. النتائج: دلت النتائج على وجود انخفاض دعنودي لتركيز المغنيسيوم في مصل دم مرضى السكري بالمقارنة مع الحالات الضابطة. كما دلت النتائج على وجود ارتفاع معنوي لتركيز السكر في مصل دم مرضى السكري بالمقارنة مع الحالات الضنابطة. الاستتتاج: أثتتت الدر اسة على ان مستوى المغنيسيوم في مصل دم مرضى السكري النوع الثاني منخفض مقارنة مع الأشخاص الأصحاء و الذين لايعانون من مرض السكري في مدينة الموصل. وبما ان انخفاض تركيز المغنيسيوم يؤدي الى في 


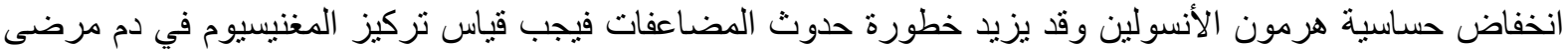

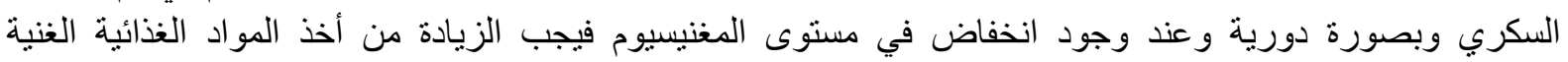

$\mathrm{M}$ agnesium deficiency has been reported in type 2 diabetes mellitus. In the United States, $25-39 \%$ of diabetic outpatients have low concentrations of serum magnesium (1). Low serum magnesium concentrations in patients with type 2 diabetes have also been reported in several European countries, e.g., Austria, Germany, Italy, France, and Sweden (2-5)

Magnesium is the fourth most abundant cation in the human body and the second most abundant intracellular cation. It may exist as a protein bound, complexed, or free cation. It serves as a co-factor for all enzymatic reactions that require ATP and as a key component in various reactions that require kinases. It is also an essential enzyme activator for neuromuscular excitability and cell permeability, a regulator of ion channel and mitochondrial function, a critical element in cellular proliferation and apoptosis, and an important factor in both cellular and humoral immune reactions ${ }^{(6)}$.

Magnesium depletion has a negative impact on glucose homeostasis and insulin sensitivity in patients with type 2 diabetes, as well as on the evolution of complications such as retinopathy, thrombosis and hypertension. Moreover, low serum magnesium is a strong independent predictor of the development of type 2 diabetes ${ }^{(7)}$.

A large body of evidence that shows a link between hypomagnesemia and reduction of tyrosine kinase activity at the insulin receptor level, which may result in the impairment of insulin action and development of insulin resistance, has been progressively accumulated in previous years ${ }^{(8)}$. Although evidence suggests that magnesium supplementation could be useful in the treatment of diabetes and to prevent the development of its chronic complications, the possible benefits of magnesium administration as an adjuvant factor for the treatment of type
2 diabetes, based in a randomized controlled trial, are scarce and controversial ${ }^{(8)}$.

The aim of this study was to determine the serum magnesium concentrations of patients with type 2 diabetes on hypoglycemic therapy and healthy controls in Mosul city.

\section{Patients and methods}

One hundred type 2 diabetic patients and 27 non diabetic controls participated in the study. The patient's group was divided into 3 groups according to the type of the oral hypoglycemic agent used (metformin, glibenclamide, metformin plus glibenclamide) (table 1). The diabetic patients were recruited from Al-Wafaa Center of Diabetes Mellitus in Mosul city. Twenty six of the patients were taking metformin, 32 were taking glibenclamide, and 42 were using both. The doses of the drugs ranged from $500 \mathrm{mg}$ to $2000 \mathrm{mg}$ daily in case of metformin and 5 to $10 \mathrm{mg}$ in case of glibenclamide. Durations of treatment were $2.65 \pm 2.76$ years in case of metformin, $4.01 \pm 4.52$ years in case of glibenclamide and $3.62 \pm 3.13$ years in case of met+glib therapy.

Because loop diuretics are associated with higher urinary magnesium excretion, patients on loop diuretics were excluded. None were taking magnesium supplements. The study protocol was approved by the Ethical Committee of the College of Medicine, University of Mosul.

Venous blood samples from the fasting control subjects and patients were drawn. Serum was separated from blood cells by centrifugation at $3000 \mathrm{rpm}$ for 15 minutes and stored at $-25^{\circ} \mathrm{C}$ until analysis.

Quantitative analysis of magnesium in serum was done by a photometric method ${ }^{(9)}$ available as a commercial kit for measurement of magnesium (Biolabo, France). Serum glucose concentrations were estimated by glucose oxidase peroxidase colorimetric method ${ }^{(10)}$ available as a kit provided by Randox Company, UK. 
Table (1): Patient's and control's characteristics.

\begin{tabular}{|l|c|c|c|c|}
\hline \multicolumn{1}{|c|}{ Parameters } & Control & Metformin & Glibenclamid & Met+Glib \\
\hline Age & $52.7 \pm 9.39$ & $52.04 \pm 9.46$ & $51.03 \pm 7.61$ & $57.79 \pm 9.86$ \\
\hline Male/ Female & $12 / 15$ & $17 / 9$ & $15 / 17$ & $22 / 20$ \\
\hline Duration of treatment & ------ & $2.65 \pm 2.76$ & $4.01 \pm 4.52$ & $3.62 \pm 3.13$ \\
\hline No Patients & 27 & 26 & 32 & 42 \\
\hline
\end{tabular}

Statistical analysis: Unpaired t-test was used to compare serum magnesium or glucose concentrations of the controls and the patients. Linear regression analysis (Pearson Correlation Coefficient, $r$ ) was performed for finding the degree of association between serum glucose concentration and serum magnesium concentration. Level of significance at 0.05 or less.

\section{Results}

Mean serum magnesium concentrations of the diabetics and the controls appeared in (table 2). A significant lower level of magnesium as compared with those of the control individuals, were obtained from the patients $(P=0.001$ for metformin, 0.004 for glibenclamide, and 0.0001 for the drug's combination).

Mean serum glucose concentrations of the diabetic group were significantly higher as compared with those of the control group, and were uncontrolled cases as evident by their high serum concentrations (table 3 ).

No correlation was found between serum glucose concentration and serum magnesium concentration of the different groups ( $r=-0.035$ for glibenclamide, $P=0.84 ; \quad r=0.26$ for metformin, $\mathrm{P}=0.21 ; \mathrm{r}=0.07$ for met+glib, $\mathrm{P}=$ 0.66).

Table (2): Serum magnesium concentrations in the control and patient's groups $(\mathrm{mg} / \mathrm{dl})$ (Mean \pm sd).

\begin{tabular}{|l|c|}
\hline \multicolumn{1}{|c|}{ Group } & $\begin{array}{c}\text { Serum Magnesium } \\
\text { Concentration }\end{array}$ \\
\hline Control & $2.22 \pm 0.69$ \\
\hline Metformin & $1.59 \pm 0.63$ \\
\hline Glibenclamide & $1.68 \pm 0.70$ \\
\hline Met+Glib & $1.30 \pm 0.72$ \\
\hline
\end{tabular}

Control values significantly differs from patient's values: P Values; 0.001 for metformin; 0.004 for glibenclamide and 0.0001 for met+glib combination.
Table (3): Serum glucose concentrations in the control and patient's groups $(\mathrm{mg} / \mathrm{dl})$ (Mean \pm sd).

\begin{tabular}{|l|l|}
\hline \multicolumn{1}{|c|}{ Group } & $\begin{array}{l}\text { Serum glucose } \\
\text { Concentration }\end{array}$ \\
\hline Control & $113.29 \pm 59.34$ \\
\hline Metformin & $189.21 \pm 79.79$ \\
\hline Glibenclamide & $222.97 \pm 85.35$ \\
\hline Met+Glib & $231.14 \pm 92.10$ \\
\hline
\end{tabular}

Control values significantly differs from patient's values: $\mathrm{P}$ Value; $<0.001$ for metformin; glibenclamide and met+glib combination.

\section{Discussion}

The results in the present study showed that diabetic patients had low level of serum magnesium as compared with the control healthy subjects in Mosul city.

Similar findings have been obtained by other researchers in other countries. Pham et al. ${ }^{(6)}$ stated that hypomagnesemia has been reported to occur at an increased frequency among patients with type 2 diabetes compared with their counterparts without diabetes in USA. Al-Osali et al. ${ }^{(11)}$ showed that low total serum levels of magnesium are frequently seen in type 2 diabetic Omani patients. Seyoum et al. ${ }^{(12)}$ reported that Ethiopians patients with diabetes mellitus have lower levels of magnesium and therefore at increased risk of complications related to magnesium. Low levels of magnesium in type 2 diabetic patients have also been reported in other countries including Italy ${ }^{(13)}$, India ${ }^{(14)}$, and Bangladesh $^{(15)}$.

The reasons for the high prevalence of magnesium deficiency in diabetes are not clear, but may include increased urinary loss, lower dietary intake, or impaired absorption of magnesium compared to healthy individuals ${ }^{(7)}$. Several studies showed that intake of magnesium can correct the magnesium status 
of the diabetic patients. Rodriguez-Moran and Guerrero $^{(8)}$ reported that oral supplementation with magnesium chloride solution restores serum magnesium levels, improving insulin sensitivity and metabolic control in type 2 diabetic patients with decrease magnesium levels. De Lordes Lima ${ }^{(16)}$ showed that magnesium depletion is common in poorly controlled patients with type 2 diabetes, especially in those with neuropathy or coronary disease. More prolonged use of magnesium in doses that are higher than usual is needed to establish its routine or selective administration in patients with type 2 diabetes to improve control or prevent chronic complications.

In the present study no correlation was found between serum glucose concentrations and serum magnesium levels. Several authors have described a correlation between $\mathrm{HbA1c}$ and plasma magnesium magnesium in type 1 diabetics ${ }^{(4,17)}$. However, no such a correlation was found in type 2 diabetes ${ }^{(4,18,19)}$, similar to our results.

Clinically, there are significant data linking hypomagnesemia to various diabetic micro and macrovascular complications. In a study that involved 19 normotensive individuals without diabetes, 17 hypertensive individuals without diabetes, and 6 hypertensive individuals with diabetes, Resnick et al. ${ }^{(20)}$ documented the lowest mean intracellular magnesium concentration among the last group. Two studies showed that not only did patients with diabetes have lower serum magnesium levels compared with their counterparts without diabetes, but also the serum magnesium levels among the cohort with diabetes had an inverse correlation with the degree of retinopathy ${ }^{(21,}{ }^{22)}$. In a comparative study that involved 30 patients who had type 2 diabetes without microalbuminuria, 30 with microalbuminuria, and 30 with overt proteinuria, Corsonello et al. (23) observed a significant decrease in serum ionized magnesium in both the microalbuminuria and overt proteinuria groups compared with the nonmicroalbuminic group. There also are data to suggest the association between hypomagnesemia and other diabetic complications, including dyslipidemia and neurologic abnormalities ${ }^{(24)}$.

Serum glucose concentrations, in the present study, were high (the patient's diabetic state is uncontrolled, in spite of using of hypoglycemic agents). Several studies have shown elevated urinary magnesium excretion in both type 1 and 2 diabetic patients, and elevated urinary magnesium excretion in diabetes is associated with elevated fasting blood glucose and $\mathrm{Hb} \mathrm{A}_{1 \mathrm{c}}$ concentrations $^{(7)}$. The lower magnesium concentrations in the present study may be due to the elevated levels of glucose concentrations reported in the present study. Pham et al. ${ }^{(25)}$ reported that patients who have serum magnesium levels between 2.0 and 2.5 $\mathrm{mg} / \mathrm{dl}$ had the least degree of renal function deterioration and best glycemic control.

In conclusion, we have demonstrated that low magnesium status is common in type 2 diabetics who were on therapy with the hypoglycemic agents, metformin or glibenclamide or a combination of both drugs, in Mosul city in Iraq.

\section{References}

1. Nadler JL, Rude RK. Disorders of magnesium metabolism. Endocrinol Metab Clin North Am 1995; 24:623-641.

2. Schnack C, Bauer I, Pregant P, Hopmeier $P$, Schernthaner $G$. Hypomagnesaemia in type 2 (non-insulin-dependent) diabetes mellitus is not corrected by improvement of long-term metabolic control. Diabetologia 1992; 35:77-79.

3. Paolisso G, Sgambato S, Giugliano D, Torella R, Varricchio M, Scheen AJ, et al. Impaired insulin-induced erythrocyte magnesium accumulation is correlated to impaired insulin-mediated glucose disposal in type 2 (non-insulin-dependent) diabetic patients. Diabetologia 1988; 31: 910-915.

4. Schlienger JL, Grunenberger F, Maier EA, Simon C, Chabrier G, Leroy MJF. Disturbances of plasma trace-elements in diabetes-relations with glycemic control. Presse Med 1988; 17:1076-1079.

5. Sjogren $\mathrm{A}$, Floren $\mathrm{CH}$, Nilsson A. Magnesium, potassium and zinc deficiency in subjects with type II diabetes 
mellitus. Acta Med Scand 1988;224:461466.

6. Pham PC, Pham PM, Pham SV, Miller JM, Pham PT. Hypomagnesimia in patients with type 2 diabetes mellitus. Clin J Am Soc Nephrol 2007; 2: 366-373.

7. Waltia MK, Zimmermanna MB, Spinasb GA, Hurrell RF. Low plasma magnesium in type 2 diabetes. Swiss Med Wkly 2003; 133: 289-292.

8. Rodriguez-Moran N, Guerrero-Romero F. Oral magnesium diabetic supplementation improves insulin sensitivity and metabolic control in type 2 subjects. A randomized double blind controlled trial. Diabetes Care 2003; 26: 1147- 1152.

9. Abemethy $\mathrm{MH}$, Fowler RT. Micellar improvement of the calmagite Compleximetric measurement of magnesium in plasma. Clin Chem 1982; 28: 520-522.

10. Lotta JA, Turner K. Evaluation of trinders' glucose oxidase method For measuring glucose in serum and urine. Clin Chem 1975; 2: 1754-1760.

11. Al_Osali ME, Al-Qassabi SS, Elsayed MK. Hypomagnesemia in type 2 diabetic Omani patients. Saudi Med J 2009; 30: 897-901.

12. Seyoum B. Siraj ES, Saenz C, Abdulkadir J. Hypomagnesemia in Ethiopians with diabetes mellitus. Ethn Dis 2008; 18: 147151.

13. Corica F, Corsonello A, Lentile R, Cucinotta D, Di Benedetto A, Perticone F, et al. Serum ionized magnesium levels in relation to metabolic syndrome in type 2 diabetic patients. J Am Coll Nutr 2006; 25 : 210- 215.

14. Lal J, Vasudev K, Kela AK, Jain SK. Effect of oral magnesium Supplementation on the lipid profile and blood glucose of patients with type 2 diabetes mellitus. J Assoc Physicians India 2003; 51: 37-42.

15. Khan LA, Alam AM, Ali L, Goswami A, Hassan Z, Sattar $S$, et al. Serum and urinary magnesium in young diabetic subjects in Bangladesh. Am J Clin Nutr 1999; 69: 70-73.
16. de Lordes Lima M, Cruz T, Pousada JC, Rodrigues LE, Barbosa K, Cangucu V. The effect of magnesium supplementation in increasing Doses on the control of type 2 diabetes. Diabetes Care 1998; 21: 682686.

17. Sjogren A, Floren $\mathrm{CH}$, Nilsson $\mathrm{A}$. Magnesium deficiency in IDDM Related to level of glycosylated hemoglobin. Diabetes 1986; 35: 459-463.

18. de Valk HW. Hypomagnesemia and type 2 (non insulin dependent) Diabetes mellitus. Diabetologia 1992; 35: 904-905.

19. 19. Vanroelen WF, Van Gaal LF, Van Rooy PE, De Leeuw IH. Serum and erythrocyte magnesium levels in type 1 and type II diabetics. Acta Diabetol lat 1985; 22: 185-190.

20. Resnick LM, Gupta RK, Gruenspan H, Laragh $\mathrm{JH}$. Intracellular free Magnesium in hypertension: Relation to peripheral insulin resistance. J Hypertens 1988; 6(Suppl 4): s199-s201.

21. McNair P, Christiansen C, Modibad S, Binder C. Hypomagnesemia, a risk factor in diabetic retinopathy. Diabetes 1978; 27; 1075-1077.

22. Hatwal A, Gujral AS, Bhatia RPS, Agrawal JK, Bajpai HS. Association of hypomagnesemia with diabetic retinopathy. Acta Ophthalmol 1989; 67: 714- 716 .

23. Corsonello A, Lentile $R$, Buemi $M$, Cucinotta D, Mauro VN, Macaione S, et al. Serum ionized magnesium levels in type 2 diabetic patients with microalbuminuria or clinical proteinuria. Am J Nephrol 2000; 20: 187-192.

24. Sales CR, de Fatima Campos Pedrosa L. Magnesium and diabetes Mellitus: Their relation. Clin Nutr 2006: 25: 554-562.

25. Pham PC, Pham PM, Pham PA, Pham $\mathrm{SV}$, Miller JM, Yanagawa N, et al. Lower serum magnesium levels are associated with more rapid decline of renal function in patients with diabetes mellitus type 2. Clin Nephrol 2005; 63; 429-436. 